Western University Scholarship@Western

2004

\title{
Accounting Regimes and Fiscal Rules
}

Paul Boothe

Western University

Follow this and additional works at: https://ir.lib.uwo.ca/iveypub

Part of the Business Commons

Citation of this paper:

Boothe, Paul, "Accounting Regimes and Fiscal Rules" (2004). Business Publications. 22.

https://ir.lib.uwo.ca/iveypub/22 


\title{
ACCOUNTING REGIMES AND FISCAL RULES
}

\author{
Paul Boothe*
}

\section{Introduction}

Over the past twenty years, economists have invested a good deal of effort in studying the economic, political and institutional determinants of fiscal policy. ${ }^{1}$ Part of that literature has focused on fiscal rules - commitments by political leaders to certain norms of fiscal behaviour. The creation of the European Monetary Union (EMU) and the related Stability and Growth Pact (SGP) provided strong motivation to examine all aspects of fiscal rules and their impact on fiscal policy in Europe.

At the same time, a parallel literature was developing in the area of public sector accounting. Professional accounting bodies like the International Federation of Accountants (IFAC) began to advocate that traditional methods of accounting for public sector activities be changed to mirror more closely accounting in the private sector. International organizations such as the International Monetary Fund (IMF) and the Organization for Economic Cooperation and Development (OECD) have also recommended such changes in public sector accounting regimes.

With the economic impacts of various fiscal rules now relatively well understood and the political determinants of fiscal policy extensively studied, attention has turned to the impact of budget institutions on fiscal policy outcomes. ${ }^{2}$ The purpose of this paper is to contribute to this emerging literature by examining the interaction of accounting regimes and fiscal rules. In particular, we look at the incentives for policy makers that are created when governments change the way that they account for capital - a change that is currently underway in Canada and a number of other countries.

The remainder of the paper is organized as follows. A brief look at some relevant literature concludes this introduction. We next develop a simple, dynamic simulation model of a government budget to aid in analyzing the accounting regime-fiscal rule interaction. The model is first employed to examine the impact of accounting regimes on some standard fiscal rules related to deficits, government debt and the accumulation of public-sector capital. We then turn to the incentives created by accounting regimes when governments have preferences regarding the mix of capital versus operating spending or find themselves in different fiscal

\footnotetext{
Professor and Director, Institute for Public Economics - University of Alberta, EnCana Scholar in Public Policy, CD Howe Institute. Paper prepared for the Banca d'Italia Fiscal Policy Workshop, Perugia, April 2004. The views expressed in this paper are my own and should not be attributed to any other individual or institution. I am grateful to R. Boothe for valuable research assistance.

1 For a recent survey, see Alesina and Perotti (1999).

2 For example, see Poterba and von Hagen (1999).
} 
circumstances regarding starting values for deficits, debts or capital stock. The recent experience of Canadian provinces is briefly reviewed before we offer some policy conclusions.

\section{Some relevant literature}

According to Tanzi (2003), the virtues of a balanced budget have long been recognized. He cites as his authorities well-know historical figures such as Cicero, David Hume and George Washington (p.4). While it is unlikely that such individuals concerned themselves with public sector accounting, Wynne (2003) tells us that the cash basis of accounting has been used to measure fiscal balance for the last 150 years. $^{3}$ Of course, regardless of accounting regime, there are many methodological issues related to the measurement of fiscal balance (Blejer and Cheasty, 1991). As well, fiscal rules are more or less effective depending on their design and a host of other, external factors (Kopits, 2001). ${ }^{4}$

Research has shown that one of the key external factors affecting fiscal policy outcomes is budget institutions. For example, Poterba and von Hagen claim that "[h]igher levels of transparency are associated with lower budget deficits." Further, they go on to argue that "...institutions must themselves be regarded as endogenous. The questions when, and why, governments adopt institutional reforms remain important challenges for future research in the political economy of fiscal policy" (p. 4).

An important institutional reform currently underway in developed countries is the move from cash to accrual accounting for capital. Analysts' views on this change are mixed. Proponents argue that such a change will correct an inherent bias against the accumulation of public sector capital inherent in a cash accounting regime. ${ }^{5}$ For example, Balassone and Franco (2001) point to the double burden of transition to balanced budget and lower debt levels and the impact of consolidated balance fiscal rules on public investment.

However, others are less supportive of the move to accrual accounting for capital. They cite the benefits flowing from the simplicity of cash

3 It is useful at this point to define more precisely the terms "cash" and "accrual" accounting. Until recently, many governments in developed countries have employed what accountants call "modified accrual accounting". Under this accounting regime, physical capital is treated as an expenditure in the year it is constructed and no depreciation of the capital is charged as an expense in subsequent years. Because we are focusing in this paper on the accounting treatment of capital, we will call this regime "cash accounting". We will call the regime where capital is not expensed and depreciation is charged "accrual accounting". This corresponds to what accountants sometimes call "full accrual".

4 For example, von Hagen et al. (2002) show that fiscal consolidation based on expenditure reductions more likely to succeed than those based on revenue increases. This is confirmed for Canada in Boothe and Reid (2001).

5 Proponents include Blanchard and Giavazzi (2003), Brunila et al. (2001), Buti et al. (2992), Dur et al. (1997), Robinson (1999) and Salinas (2002) 
accounting-including accountability and ease of administration. ${ }^{6}$ For example, Tanzi (2003) quotes Financial Times columnist John Plender's 2003 article that argues that "...the further the budget discussion moves from cash, the greater the risk of becoming lost in the fiscal fog of war" (April 4, 2003, p. 18). Indeed Canada's Public Sector Accounting Board recommends that the cash accounting focus on the government deficit be replaced with five separate measures under accrual accounting (PSAB, 2003).

In this paper, we take no position on the desirability of cash versus accrual accounting regimes for the public sector. Rather, we take our inspiration from Poterba and von Hagen to look at when and why governments may choose to move from one accounting regime to the other.

\section{The model}

To help analyze the interaction of fiscal rules and accounting regimes, we construct a simple, dynamic model of a government budget. The equations describing the model are presented in Table 1. The model is recursive and deterministic, combining accounting identities with government behaviour described by various fiscal rules. We begin by describing a cash accounting regime.

\subsection{Cash accounting model}

The revenue side of the government budget is exogenous. Total revenue, $R$, grows at the (exogenous) growth rate of the economy, $g$. Total expenditure, $E$, is the sum of transfers to individuals and firms, TRN, gross public sector investment, $I$, services to individuals and firms, $S E R$, and debt service payments, $D S$. The budget surplus, $S$, is simply the difference between total revenue and total expenditure. The model is closed by a budget-balance rule where $T R N$ is determined residually to ensure $S=0$ in each period.

Investment is determined by fiscal rule for capital accumulation. In this basic model, the government sets the capital-revenue ratio, $K / R$, equal to a constant, so that $I$ is set to ensure the desired growth in the capital stock is realized, i.e. so that $K=g^{*} K(-1)$. Services are provided by operating public capital and are set equal to a fixed proportion, a, of last period's capital stock. Debt service costs are determined by applying the interest rate on government debt/assets, $r$, to the last period stock of government financial assets/debt, $A(-1)$. The capital stock depreciates, $D E P$, at a constant rate, $d$. The model is completed by identities that account for the growth of $\mathrm{K}$ and $\mathrm{A}$.

6 Skeptics include Wynne (2003) and Tanzi (2003). Diamond (2002) is cautious in recommending the change to developing countries that may not have the systems in place to support accrual accounting. 
Table 1

\section{Basic Cash Accounting Model}

$$
\begin{aligned}
& R=(1+g)^{*} R(-1) \\
& E=T R N+I+S E R+D S \\
& S=R-E \\
& T R N=R-I-S E R-D S \\
& I=g^{*} K(-1)+D E P \\
& S E S=a^{*} K(-1) \\
& D S=-r^{*} A(-1) \\
& D E P=d^{*} K(-1)
\end{aligned}
$$$$
\text { total revenue }
$$$$
\text { total expenditure }
$$$$
\text { Surplus }
$$$$
\text { transfers expenditure (no deficit rule) }
$$$$
\text { gross public investment (constant } \mathrm{K} / \mathrm{R} \text { rule) }
$$$$
\text { services expenditure }
$$$$
\text { debt service expenditure }
$$$$
\text { Depreciation }
$$$$
\text { capital stock }
$$$$
\text { financial assets }
$$

\section{Basic Accrual Accounting Model}

Replace (2), (4) and (10) with:

$\begin{array}{ll}E=T R N+S E R+D S+D E P & \text { total expenditure } \\ T R N=R-S E R-D E P-D S & \begin{array}{l}\text { transfers expenditure (no operating deficit } \\ \text { rule) } \\ \text { financial assets }\end{array}\end{array}$

\section{Variables}

$R$ is total revenue

$g$ is revenue (economy) growth rate

$E$ is total expenditure

$T R$ is transfer expenditure

$S E R$ is services expenditure

$D S$ is debt service

$S$ is surplus

$I$ is gross investment

$a$ is cost of operating capital

$K$ is capital stock

$r$ is interest rate on financial assets/debt

$A$ is financial assets/debt

$D E P$ is depreciation

$d$ is depreciation rate 


\subsection{Accrual accounting model}

To transform the basic cash accounting model of the government budget into one that conforms to an accrual accounting regime, we modify the definition of total expenditure and accumulation identity for government financial assets/debt. Under accrual accounting, spending on public sector capital is excluded from total expenditure, while the depreciation of public sector capital is included. Thus equation (2) becomes:

$$
E=T R N+E S+D S+D E P
$$

The anti-deficit rule under an accrual accounting regime become a anti-“operating deficit" rule. Thus, equation (4) becomes:

$$
T R N=R-S E R-D E P-D S
$$

As we shall see, the change in the fiscal rule from no cash deficit to no operating deficit has important implications for budget outcomes.

The accumulation identity for government financial assets/debt, equation (10), becomes:

$$
A=A(-1)+S-(I-D E P)
$$

In words, any net investment in capital that cannot be financed from the government's operating surplus must be financed by borrowing.

\subsection{Calibrating the model}

To run simulations we need to calibrate the model by specifying parameters and starting values for variables. The parameters and starting values are presented in Table 2 and are chosen to roughly correspond to the budget of the Canadian province of Alberta. ${ }^{7}$ Revenues are set at $\$ 20$ billion and grow at an annual rate of 5 per cent. The budget is initially in balance. Public sector capital and government rate on government debt are both set at 5 per cent. The ongoing cost of providing government services is equal to 25 per cent of the capital stock. Investment is chosen to maintain a constant ratio of capital to revenue and transfers are determined residually to ensure budget balance.

\section{A double-virtue fiscal authority}

To establish a benchmark, we begin by looking at what we describe as a "double-virtue" government, where "virtues" refer to components of their fiscal rules. In this benchmark case, the first virtue is a rule for the accumulation of public

7 In reality, the Province of Alberta is a net creditor rather than a net debtor. 
Table 2

Parameters

\begin{tabular}{|c|c|}
\hline$g$ & 0.05 \\
\hline$a$ & 0.25 \\
\hline$r$ & 0.05 \\
\hline$d$ & 0.05 \\
\hline
\end{tabular}

Starting Values

\begin{tabular}{|c|r|}
\hline$R$ & 20.00 \\
\hline$E$ & 20.00 \\
\hline$T R N$ & 16.17 \\
\hline$I$ & 0.95 \\
\hline$S E R$ & 2.35 \\
\hline$D S$ & 0.50 \\
\hline$K$ & 10.00 \\
\hline$D E P$ & 0.48 \\
\hline$A$ & -10.00 \\
\hline
\end{tabular}

sector capital, i.e. that a constant ratio of capital to revenue be maintained, i.e. $K / R=2 .{ }^{8}$ The second virtue is an anti-deficit rule, i.e. $S=0$. Under a cash regime, the two rules imply that a portion of current revenue must be reserved to fund new capital. Under an accrual regime, capital accumulation can be financed by borrowing.

Figure 1 shows the results produced by the interaction of the accounting regimes and the fiscal rules. We see that the level of financial debt is constant under cash accounting, growing with accrual accounting. The mix of spending also differs across accounting regimes. In the case of the cash regime, capital spending is financed by current revenue, reducing the revenue available for other purposes. In the accrual regime, capital spending is partially financed by borrowing, leaving more revenue available for other purposes. However, as debt accumulates so do interest charges, which reduces the revenue available for other spending. Under the current parameterization, at the ten-year horizon, the former effect outweighs the latter and transfers are greater under accrual than under cash accounting. ${ }^{9}$

The results presented in Figure 1 lead to a well-known, but nevertheless important policy implication. Changes in accounting regimes may require corresponding changes to fiscal rules. Maintaining the same fiscal rules while changing accounting regimes, may result in important changes in the trajectory of public debt and the mix of expenditures over time.

8 It is easy to imagine that revenues grow in line with nominal GDP, making this a $K / G D P$ rule.

$9 \quad$ It is important to note that the differences between the results produced by the two regimes are sensitive to parameterization. The most important differences come from the choice of the growth rate of revenue, $g$. When $g$ equals zero rather than 0.5 , the results from the two models are equivalent, i.e. debt and capital are unchanged and investment is confined to depreciation. When $g$ equals -0.5 , investment is zero and debt is repaid under the accrual regime using the cash generated by expensing depreciation. 
Figure 1

Financial Assets

Constant K/R + No Deficits

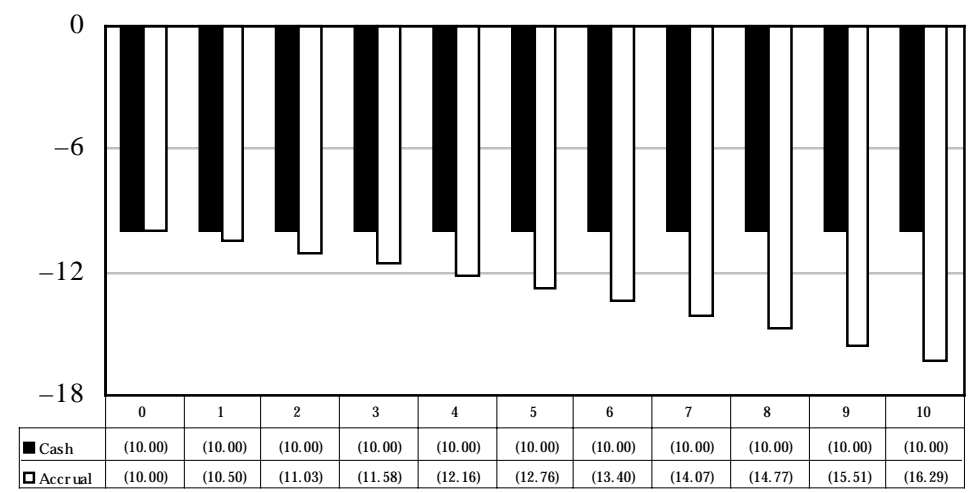

Capital

Constant K/R + No Deficits

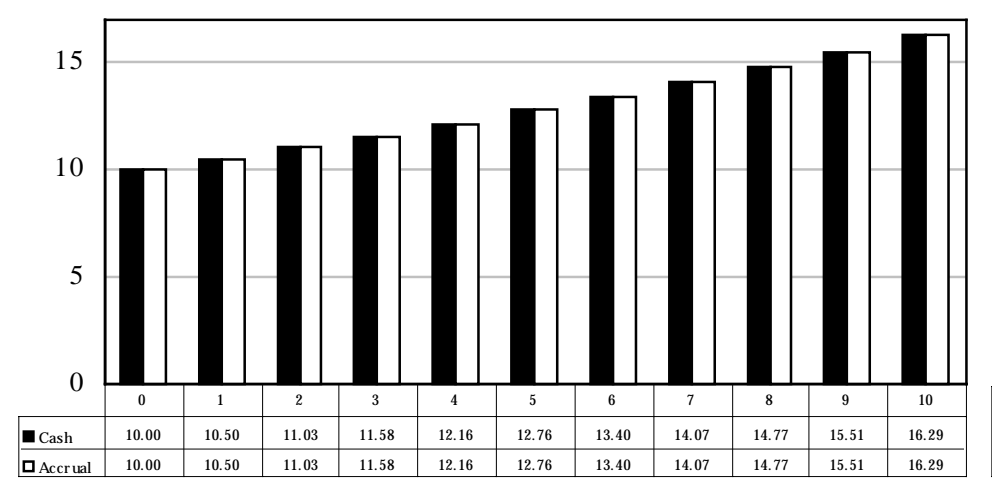

Program Expense + Investment

Cash Regime: Constant K/R + No Deficits

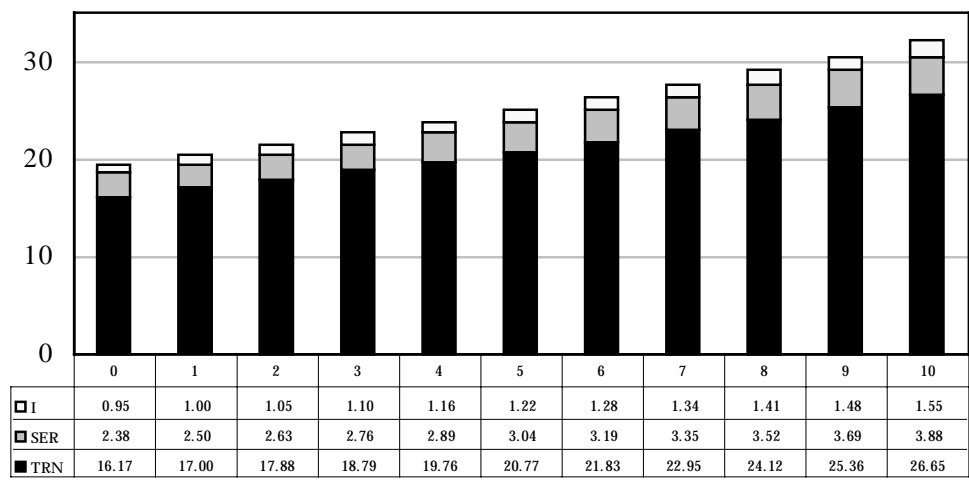

Program Expense + Investment

Accrual Regime: Constant K/R + No Deficits

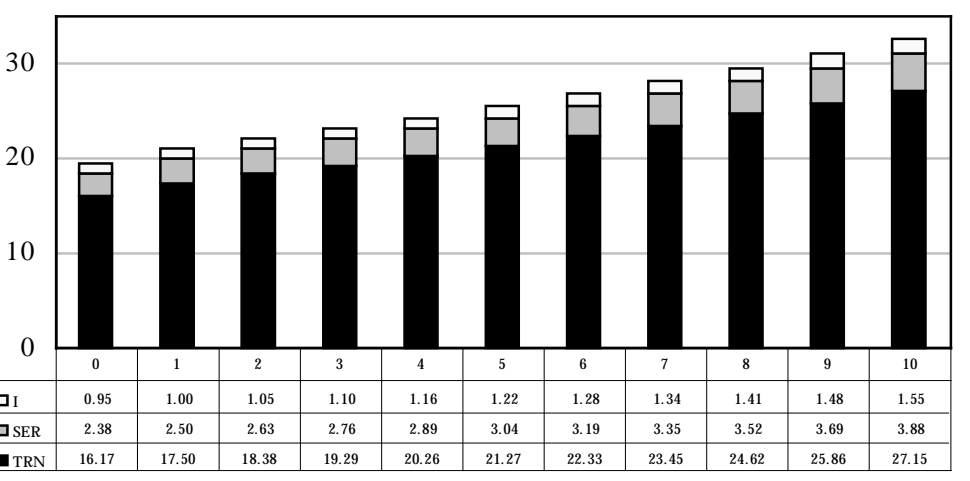




\section{Changing the authority's virtues}

To be fair to advocates of accrual accounting for the public sector, the need for new fiscal rules and corresponding indicators to accompany the change of accounting regime has long been recognized. ${ }^{10}$ One such rule change is to focus attention on changes in government debt rather than deficits. In this section, we replace our "anti-deficit" rule with a rule that requires that a constant ratio of debt to revenue be maintained, i.e. $A / R=2 .{ }^{11}$ We retain our rule regarding the ratio of capital to revenue from the previous section.

To implement the new rule under the cash accounting regime, we modify equation (4) so that now transfers ensure that a constant debt/revenue ratio is maintained:

$$
T R N=R+g^{*} A(-1)-I-S E R-D S
$$

No changes are required to implement the rule under an accrual accounting regime. In other words, an anti-deficit rule and a constant $A / R$ rule are equivalent under accrual accounting.

The results for key variables under the two accounting regimes and $g=0.5$ are presented in Figure 2. As we can see, the two regimes produce equivalent results despite the fact that deficits are incurred under cash accounting while they are not under accrual accounting. These findings lead to the (again) well-known policy implication that key fiscal trajectories under a debt rule are insensitive to the choice of accounting regimes. We tested the sensitivity of this finding to changes in $g$ and confirmed that results are similar across regimes when $g=0$. In this case neither regime records deficits. When $g=-.0 .5$, results are again similar although cash accounting records surpluses, while accrual does not. In addition, we tested different fiscal rules for debt (for example, declining $A / R$ ) and again found that results were similar across regimes.

\section{A single-virtue fiscal authority}

It is indeed a virtuous fiscal authority that constrains its actions by rules for both deficits or debts and capital accumulation. Much more common are situations where governments specify rules for deficits or debt but are unconstrained with respect to public sector capital. Indeed, as discussed above, one of the key reasons periods of deficit reduction, governments using cash accounting simply replaced fiscal deficits with "infrastructure" deficits by ignoring the depreciation of their capital.

\footnotetext{
10 See PSAB (2003).

11 As before, this could be easily thought of as a Debt/GDP rule.
} 
Table 2

Financial Assets

Constant K/R + Debt Rule

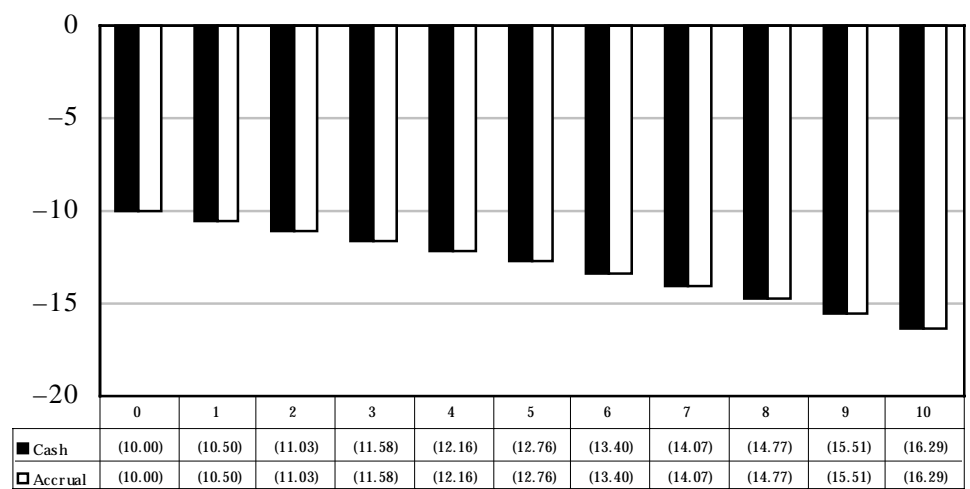

Capital

Constant K/R + Debt Rule

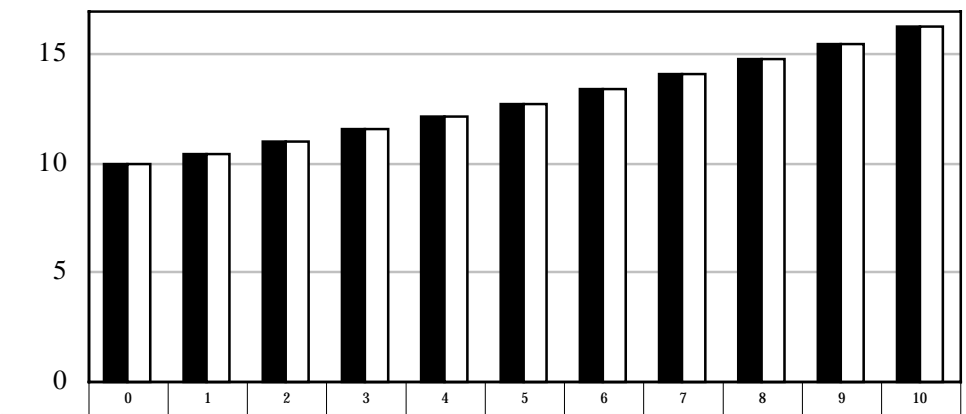

Program Expense + Investment

Cash Regime: Constant K/R + Debt Rule

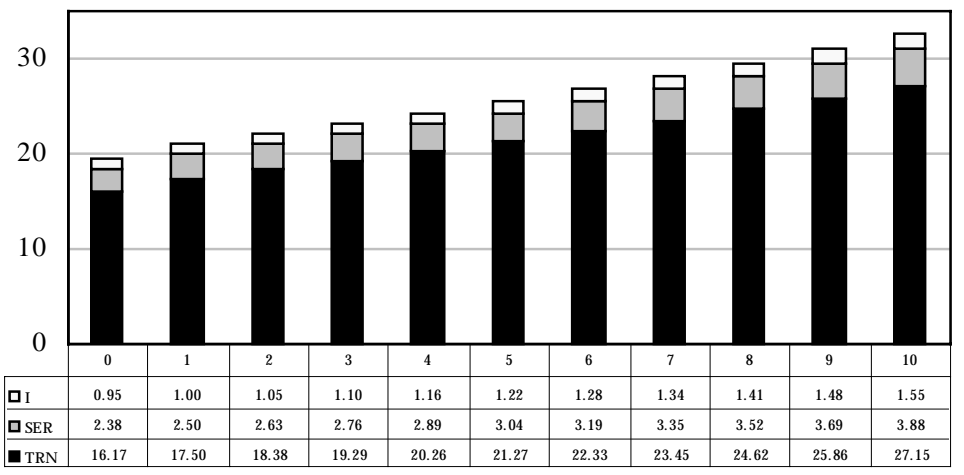

Program Expense + Investment

Accrual Regime: Constant K/R + Debt Rule

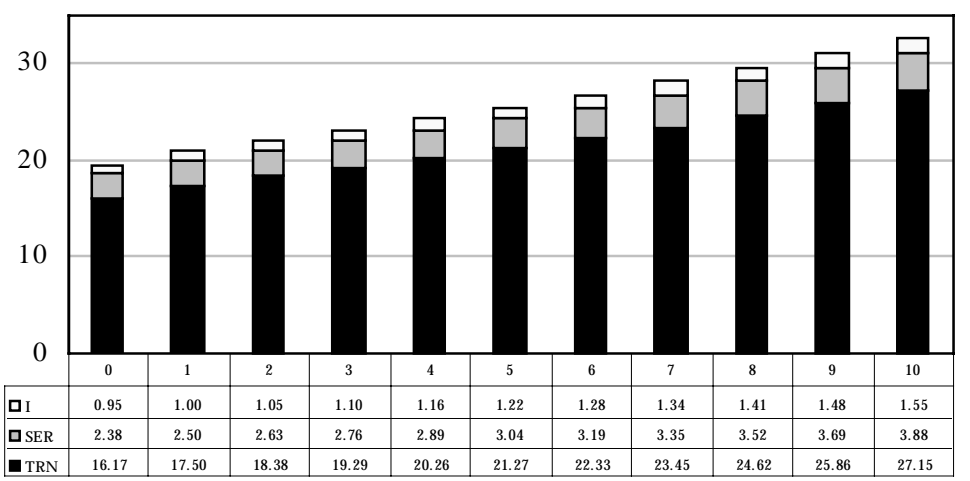




\subsection{Deficit elimination rules}

In Figure 3 we present results from a simulation where fiscal authorities want to eliminate an existing deficit but are unconstrained with respect to the level of public capital. We assume that authorities begin with a deficit equal to $\$ 4$ billion (excess transfers) and commit to reduce it by $\$ 1$ billion per year so that it is eliminated by the fourth year of their mandate. ${ }^{12}$ Subject to the deficit elimination constraint, we assume that authorities' objective is to maximize operating spending, i.e. the sum of $T R N+S E R$.

In any given period, authorities must choose between providing transfers or investing in additional capital. Whether they operate under a cash or an accrual accounting regime, authorities' optimal strategy is to concentrate incremental spending on transfers. The reason is that under both regimes their deficit target requires that they forego transfers in the current period to create cash to finance investment. While the capital stock declines in an equivalent manner under both regimes, the debt trajectories and mix of spending over time differ. Under accrual accounting, the cash generated by amortization is used to reduce debt, while under cash accounting all revenue not allocated to services and debt payments can be spent on transfers. Thus, under cash accounting, transfer spending is higher.

The policy implication of these simulations is that a fiscal consolidation program is less stringent under cash accounting than under accrual. The reason is simply that under cash accounting, authorities are able "finance" a portion of the adjustment through unrecorded depreciation of capital. Or put another way, a cash deficit is easier to eliminate than an accrual deficit. Whether such a strategy is desirable or not depends on one's perspective. For policy makers searching for the least politically costly way of eliminating a structural deficit, cash accounting may be preferable - especially if the period of adjustment is relatively short and the resulting decline in public sector capital manageable.

\subsection{Capital accumulation rules}

Of course, it may be that fiscal authorities, especially those who have achieved fiscal balance, have objectives other than maximizing operating spending. For example, it may be that authorities wish to maximize capital accumulation because of the particular political benefits that flow from public investment. In Figure 4, we present the results of simulation that models such behaviour.

12 In the Canadian parliamentary system, governments customarily call general elections in the fourth year of their mandate. 
Table 3

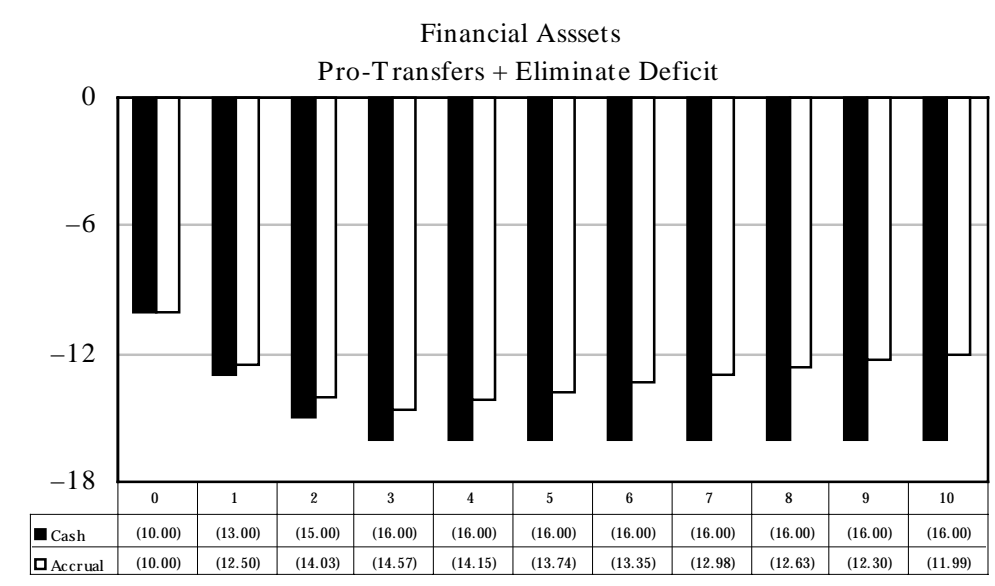

Program Expense + Investment

Cash Regime: Pro-Transfer + Eliminate Deficits

Capital

Pro-Transfers + Eliminate Deficit

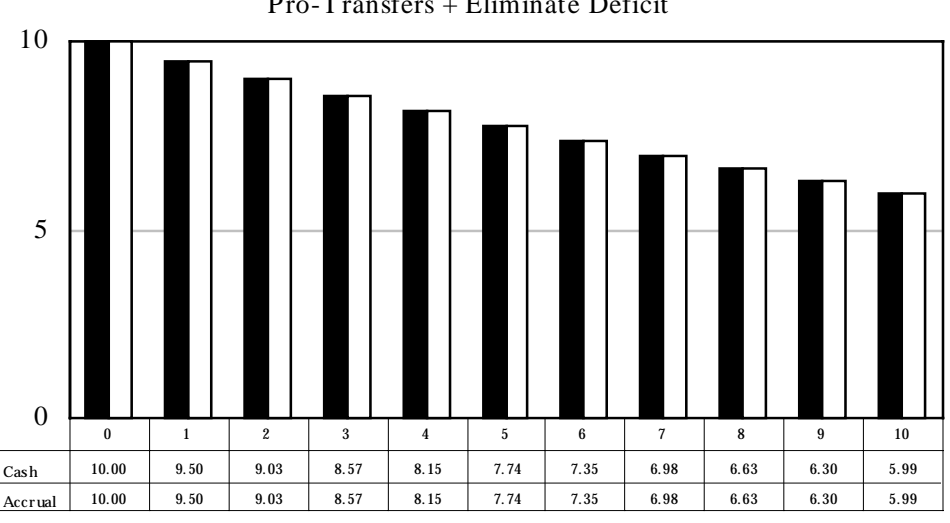

Accrual Regime: Pro-Transfer + Eliminate Deficits

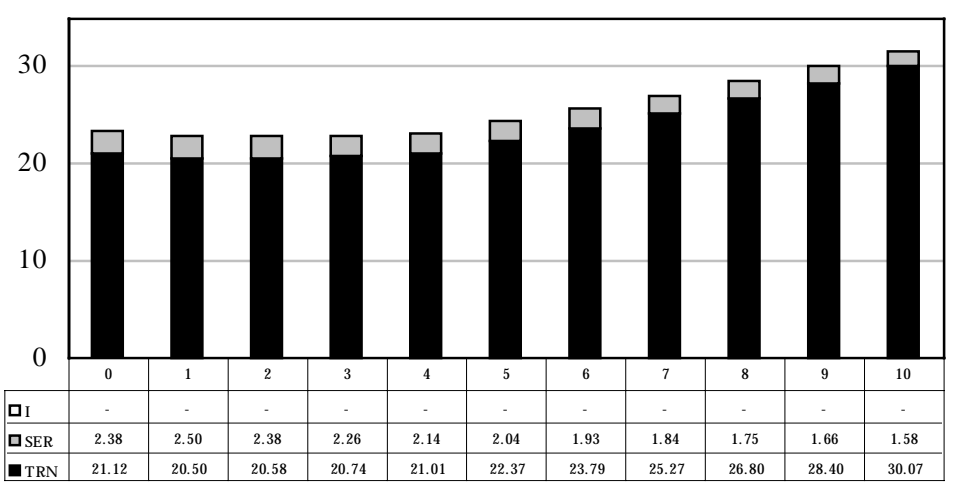


Table 4

Financial Assets

Pro-Investment + No Deficits

Program Expense + Investment

Cash Regime: Pro-Investment + No Deficits

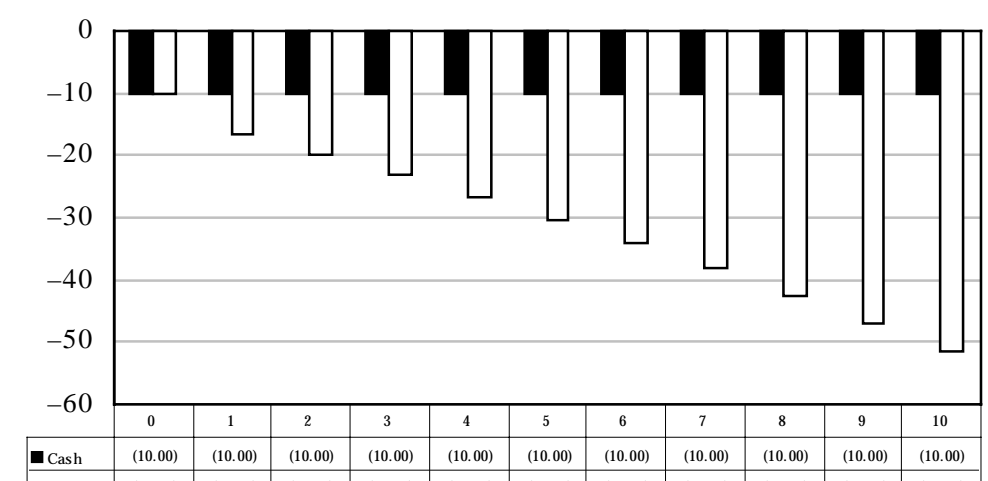

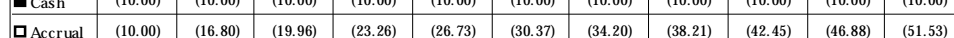

Capital
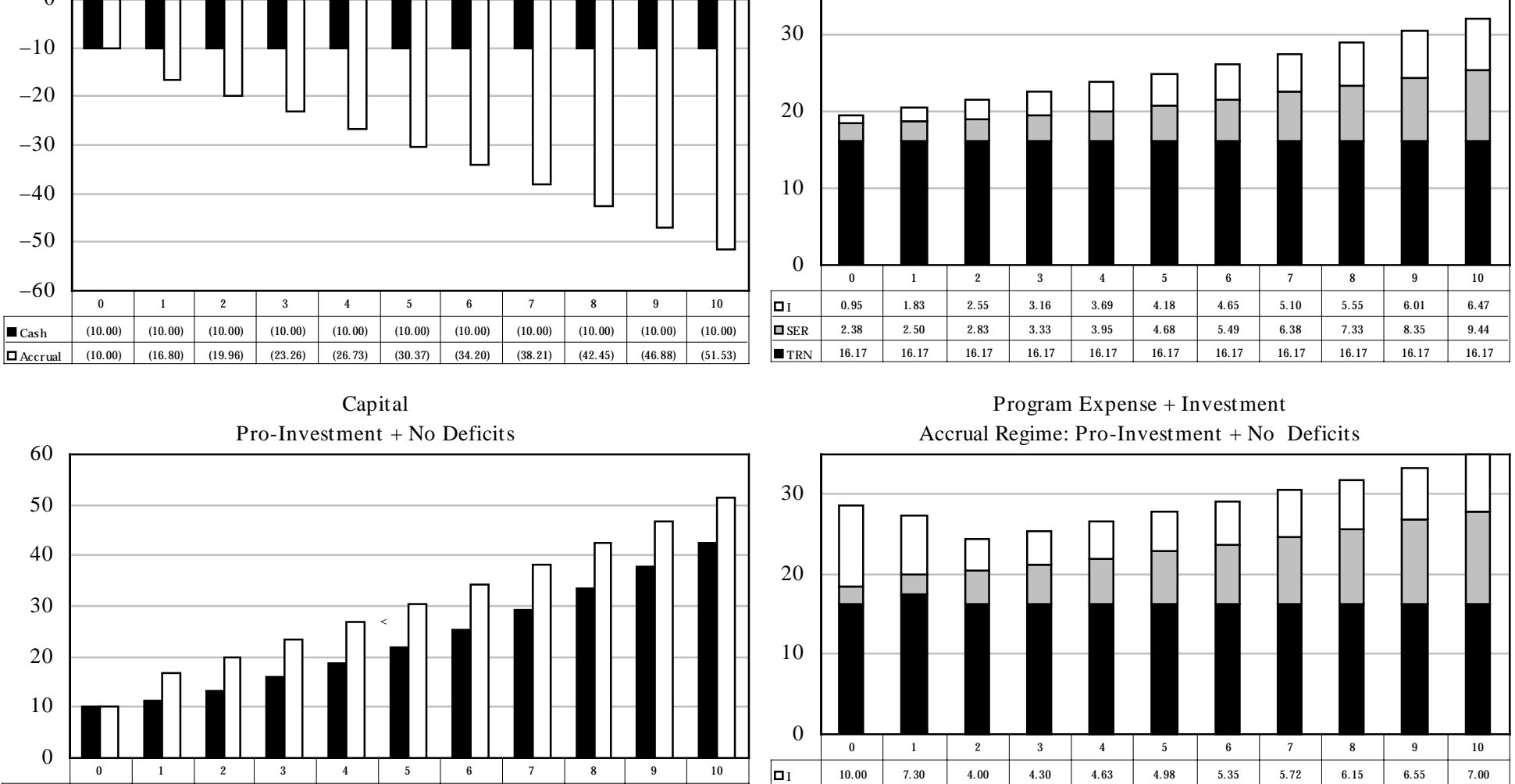

\begin{tabular}{|c|c|c|c|c|c|c|c|c|c|c|c|}
\hline ISER & 2.38 & 2.50 & 2.83 & 3.33 & 3.95 & 4.68 & 5.49 & 6.38 & 7.33 & 8.35 & 9.44 \\
\hline TRN & 16.17 & 16.17 & 16.17 & 16.17 & 16.17 & 16.17 & 16.17 & 16.17 & 16.17 & 16.17 & 16.17 \\
\hline
\end{tabular}

Program Expense + Investment

Accrual Regime: Pro-Investment + No Deficits

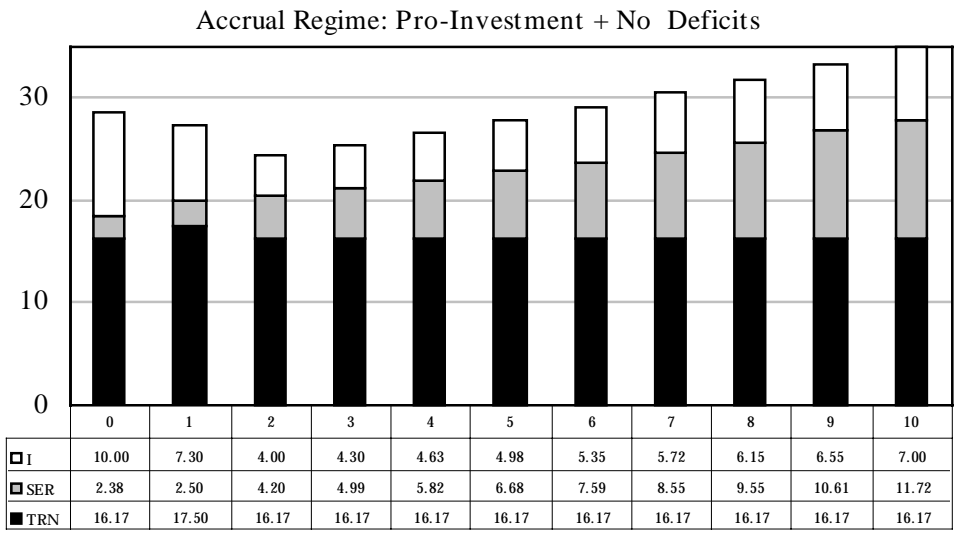


Constrained only to avoid deficits, the investment maximizing government would simply eliminate all transfer spending To avoid this unrealistic outcome, we impose the additional constraint that transfer spending cannot be reduced below its initial value. Facing these two constraints, the optimal strategy under both accounting regimes is to hold transfers constant and devote all revenue in excess of that needed to fund the operation of existing capital and debt service to new investment.

Although the optimal strategy is common to both accounting regimes, the fiscal outcomes differ substantially. In the case of cash accounting, no deficits means no borrowing, so that capital accumulation must be financed out of current revenue. In the case of accrual accounting, the accumulation of debt-financed capital does not affect the no-deficit constraint in the current period but only in future period through its impact of the level of services provided and interest payments on government debt. Thus, capital accumulation is only constrained by its impact on the budget constraint in future periods. ${ }^{13}$

In Figure 4 we see that under cash accounting, government debt remains constant, while under accrual it grows substantially. Not only is investment higher under accrual accounting but spending on services from capital is substantially higher as well. Indeed, we see that by year 10, annual operating expenditures are higher under accrual than cash accounting by almost seven per cent.

The policy implication from this simulation is that in an environment where authorities are constrained to maintain budgetary balance, governments who favor capital accumulation will find an accrual accounting regime more attractive than a cash regime.

\section{Recent Canadian experience}

Canada is one of a number of jurisdictions that is making the transition from cash to accrual accounting for the public sector. The national accounting profession's body concerned with accounting standards, the Public Sector Accounting Board recommends that governments adopt a full accrual accounting regime and that interested parties focus on five separate measures including net debt level, annual surplus, change in net debt, accumulated surplus, and statement of cash flow. A summary of Canadian provinces' fiscal rules and accounting regimes is presented in Table 3.

\footnotetext{
13 Because of the nature of this constraint, the accrual version of the model is no longer recursive. In this case the model was solved iteratively, by choosing the highest level of investment that avoided an accrual deficit in the next period.
} 
Table 3

\begin{tabular}{|c|c|c|c|c|}
\hline Province & $\begin{array}{l}\text { Accounting } \\
\text { Treatment of } \\
\text { Capital }\end{array}$ & Fiscal Rule & $\begin{array}{l}\text { Focus of Budget } \\
\text { Communications }\end{array}$ & Notes \\
\hline Newfoundland & Accrual & & $\begin{array}{l}\text { Cash } \\
\text { deficit/surplus }\end{array}$ & \\
\hline Nova Scotia & Accrual & $\begin{array}{l}\text { Budget balance over } 2 \\
\text { years, foreign debt } \\
\text { limits }\end{array}$ & $\begin{array}{l}\text { Accrual } \\
\text { deficit/surprlus } \\
\text { and Debt/GDP }\end{array}$ & \\
\hline $\begin{array}{l}\text { New } \\
\text { Brunswick* }\end{array}$ & Cash & $\begin{array}{l}\text { Budget balance over } 4 \\
\text { year term }\end{array}$ & $\begin{array}{l}\text { Cash } \\
\text { deficit/surplus }\end{array}$ & $\begin{array}{l}\text { Fund } \\
\text { accounting } \\
\text { allows savings } \\
\text { to be treated as } \\
\text { budgetary } \\
\text { revenue }\end{array}$ \\
\hline $\begin{array}{l}\text { Prince Edward } \\
\text { Island }\end{array}$ & Accrual & & $\begin{array}{l}\text { Accrual } \\
\text { deficit/surplus }\end{array}$ & \\
\hline Quebec & Accrual & $\begin{array}{l}\text { Budget balance over } 2 \\
\text { years }\end{array}$ & $\begin{array}{l}\text { Accrual } \\
\text { deficit/surplus }\end{array}$ & \\
\hline Ontario & Accrual & $\begin{array}{l}\text { Budget balance over } 2 \\
\text { years }\end{array}$ & $\begin{array}{l}\text { Accrual } \\
\text { deficit/surplus }\end{array}$ & \\
\hline Manitoba & Accrual & $\begin{array}{l}\text { Budget balance over } 2 \\
\text { years, debt targets }\end{array}$ & $\begin{array}{l}\text { Accrual } \\
\text { deficit/surplus }\end{array}$ & $\begin{array}{l}\text { Fund } \\
\text { accounting } \\
\text { allows savings } \\
\text { to be treated as } \\
\text { budgetary } \\
\text { revenue }\end{array}$ \\
\hline Saskatchewan* & Cash & $\begin{array}{l}\text { Budget balance over } 4 \\
\text { year tem }\end{array}$ & $\begin{array}{l}\text { Cash } \\
\text { deficit/surplus }\end{array}$ & $\begin{array}{l}\text { Fund } \\
\text { accounting } \\
\text { allows savings } \\
\text { to be treated as } \\
\text { budgetary } \\
\text { revenue }\end{array}$ \\
\hline Alberta & Accrual & $\begin{array}{l}\text { Restrictions on deficits } \\
\text { and debt targets }\end{array}$ & $\begin{array}{l}\text { Accrual } \\
\text { deficit/surplus plus } \\
\text { debt level }\end{array}$ & $\begin{array}{l}\text { Debt concept } \\
\text { does not } \\
\text { include new } \\
\text { borrowing for } \\
\text { capital } \\
\text { investment }\end{array}$ \\
\hline $\begin{array}{l}\text { British } \\
\text { Columbia }\end{array}$ & Accrual & $\begin{array}{l}\text { Deficit elimination over } \\
3 \text { years }\end{array}$ & $\begin{array}{l}\text { Accrual } \\
\text { deficit/surplus and } \\
\text { Debt/GDP }\end{array}$ & \\
\hline
\end{tabular}


All provinces have either moved from cash to accrual accounting for capital or have announced their intention to do so. Interestingly, none have announced changes to the fiscal rules that were put in place under the old accounting regime. At least three currently use fund rather than fully consolidated accounting so that transfers from other funds are recorded as budgetary revenue. In addition, only three of ten provinces focus their budget communications on debt as a key fiscal indicator. For one of the three, the debt concept targeted does not include borrowing for capital spending.

Thus, we see that although Canadian provincial governments are moving to accrual accounting for capital as recommended by national and international accounting bodies and other organizations, none have made corresponding changes to their fiscal rules or changed the focus of their budget communications. As a result, the change in accounting regimes has led to a significant relaxation in the discipline imposed by fiscal rules on authorities. Although it is too soon to measure with any confidence, anecdotal evidence suggests that some provincial governments are using the change in accounting regime to expand capital spending substantially.

\section{Conclusions}

The results in this paper will not be surprising to students of fiscal policy. Turning first to positive issues, because fiscal balance means different things under the two accounting regimes, rules that discourage or prohibit deficit financing are harder to satisfy under cash accounting and easier to satisfy under accrual accounting. However, fiscal rules that focus on net debt provide the same degree of fiscal discipline under both regimes.

Depending on 1) current fiscal circumstances (i.e., is the government embarking on a program of fiscal consolidation and/or debt reduction?), 2) preferences with respect to spending on capital-based services versus transfers to individuals and organizations, and 3) the trajectory of revenues (i.e. are revenues growing, shrinking or static?), authorities will prefer some combinations of accounting regimes and fiscal rules over others. For example, in periods of fiscal consolidation authorities seeking to satisfy an anti-deficit rule will prefer cash accounting because it allows some of the "deficit" to be eliminated through (unmeasured) depreciation of public sector capital. In periods of fiscal balance, authorities seeking to satisfy an anti-deficit rule will prefer accrual accounting because it allows the overall level of government spending to be higher while maintaining fiscal balance.

Turning next to normative issues, it is clear that accountability is best served if changes in public sector accounting regimes are accompanied by corresponding changes to (or, at least, clarification of) fiscal rules. Qualitative evidence from Canada suggests that this is not always the case. It is unrealistic to expect that legislators, the media and the public will be able to change their fiscal policy focus 
from a single measure, the government balance under cash accounting, to the multiple measures under accrual accounting suggested by some professional accounting bodies. Accountability might be best maintained if government adopted net debt measures as their primary fiscal indicator when operating in an accrual accounting environment. 


\section{REFERENCES}

Alesina, A. and R. Perotti (1999), "Budget Deficits and Budget Institutions", in J. Poterba and J. Von Hagen (eds.), Fiscal Institutions and Fiscal Performance, Chicago, University of Chicago Press.

Balassone, F. and D. Franco (2001), "The SGP and the Golden Rule”, in A. Brunila, M. Buti and D. Franco (eds.), The Stability and Growth Pact: The Architecture of Fiscal Policy in the EMU, Basingstoke, Palgrave.

Blanchard, O. and F. Giavazzi (2003), "Improving the SGP Through a Proper Accounting of Public Investment", CEPR, Discussion Paper, No. 4220.

Blejer, M. and A. Cheasty (1991), "The Measurement of Fiscal Deficits: Analytical and Methodological Issues", Journal of Economic Literature, Vol. 29, pp. 1644-78.

Boothe, P. and B. Reid (eds.) (2001), Deficit Reduction in the Far West, Edmonton, University of Alberta Press.

Brunila, A., M. Buti and D. Franco (eds.) (2001), The Stability and Growth Pact: The Architecture of Fiscal Policy in the EMU, Basingstoke, Palgrave.

Buti, M., S. Eijffinger and D. Franco (2002), "Revisiting the Stability and Growth Pact: Grand Design or Internal Adjustment?", CEPR, Discussion Paper, No. 3692.

Buti M., J. Von Hagen and C. Martinez-Mongay (eds.) (2002), The Behaviour of Fiscal Authorities, Basingstoke Palgrave.

Diamond, J. (2002), "Performance Budgeting - Is Accrual Accounting Required?", IMF, Working Paper, No. 02/240.

Dur, R., B. Peletier and O. Swank (1997), "The Effect of Fiscal Rules on Public Investment if Budget Deficits and Politically Motivated", Tinbergen Institute, Discussion Paper, No. 97-125/1.

Kennedy, S. and J. Robbins (2001), "The Role of Fiscal Rules in Determining Fiscal Performance", Finance Canada, Working Paper, No. 2001-16.

Kopits, G. (2001), "Fiscal Rules: Useful Policy Framework or Unnecessary Ornament?", IMF, Working Paper, No. 01/145.

Poterba, J. and J. Von Hagen (eds.) (1999), Fiscal Institutions and Fiscal Performance, Chicago, University of Chicago Press.

Public Sector Accounting Board (2003), 20 Questions about Government Financial Reporting: Federal, Provincial and Territorial Governments, Toronto, The Canadian Institute of Chartered Accountants. 
Robinson, M. (1999), "Accrual Financial Reporting in the Australian Public Sector: An Economic Perspective", Queensland University of Technology, Faculty of Business, Discussion Paper, No. 65.

Salinas, F.J. (2002), "Accrual Budgeting and Fiscal Consolidation in the EMU", Contemporary Economic Policy, Vol. 20, pp. 193-206.

Tanzi, V. (2003), "Role and Future of the Stability and Growth Pact", paper presented at the Cato Institute Conference The Future of the Euro, November, Washington (D.C.).

Von Hagen, J., A. Hughes Hallett and R. Strauch (2002), "Quality and Success of Budgetary Consolidations", in M. Buti, J. Von Hagen and C. Martinez-Mongay (eds.), The Behaviour of Fiscal Authorities, Basingstoke, Palgrave.

Wynne, A. (2003), "Do Private Sector Financial Statements Provide a Suitable Model for Public Sector Accounts?", paper presented at the European Group of Public Administration conference Public Law and Modernizing the State, September, Oeiras (Portugal). 